著作権等の理由により画像を掲載することができません。

熱波によって干上がった農業用のため池。2003 年 8 月南西フランスで撮影。

\section{A LONG DRY SUMMER}

「特集: 水」より

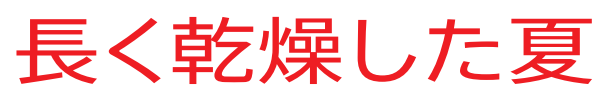

Nature Vol.452 (270-273) / 20 March 2008

現在、安定した食糧供給が期待できなくなっている地域では、今後、不安 定な気候が、土壤、植物、人々に対してさらなるストレスをかけることが予 想されている。Quirin Schiermeier が、乾燥していく世界の水戦略につ いて報告する。
2003 年にヨーロッパを襲った記録破り の熱波には、前兆があった。その年の 春は異常に乾燥しており、ヨーロッパ大 陸全体の土壌がカラカラに乾いていた のである。土壇含水量の不足は、土袞 からの水分蒸発と、それに伴う冷却効果 を激減させて、夏の猛暑を引き起こした。

気候学者は、今世紀の後半には地球 規模で温度が上昇するため、夏の猛暑 と干ばつは例外ではなく常態になると 考えている。また、ヨーロッパで年初か ら土壤含水量が急激に低下することは、 その年の夏に熱波に襲われる前兆であ るとされている ${ }^{1}$ そこには、暑さが土 猿を乾燥させ、乾燥した土壌が暑さを エスカレートさせるという悪循環が生じ ているようである。

土袞含水量の変化は、ほかにも影響 を及ぼしている可能性があり、土壌浸 食、表土流出、土袞の栄養分、雲の形 成などへの影響が考えられている。し かし、気温の上昇が土壌の乾燥に及ぼ す影響については、いまだに非常に不 確かである。気候モデル作成者たちは、 アフリカと南米に関しては、シミュレー ションした変化の徴候に確信をもつこと ができずにいる。

「私たちは、気候が变動しやすくな り、一部の地域で乾燥が進むおそれが あると教えられています。けれども、そ の詳細についてはほとんど知らされて いないのです」と、水文学者であり、 水管理の専門家である、ストックホル 么国際水研究所（スウェーデン）の Malin Falkenmarkはいう。それに もかかわらず、Falkenmarkはほか の水文学者とともに、気候の変化に応 じて水管理の方法を变えていくことを 勧告し、ようすをみる時期は終わったと よびかけている 2

「今後、気候の変化がどのように進ん でいくのか、はっきりしたことはわかり ません。けれども、变化が起こりつつあ り、何らかの準備が必要であることにつ いては、もはや疑問の余地はないので す」と Falkenmark はいう。「例えば、 一部の乾燥地域では、河川の流量が最 
大で 40 パーセントも減少する可能性が あります。それなら、水資源計画の手 法を変えていかなければなりません。実 際にそうなるまで待っているわけにはい かないのです」。

現在の気候モデルからは、雨量は増 加するが、降雨回数は減少すると予測さ れている。これは、土壌含水量が極端 に少なくなる期間が長引くことを意味し ている。北米、ヨーロッパ、アフリカ南部、 オーストラリアなど、複数の地域での観 察結果は、1 回ごとの降雨はより激しく なり、その間の乾燥した期間はより長く なるという傾向を裏づけており、この傾 向は夏に強まることがわかっている ${ }^{3}$ 。

\section{土㙵含水量を把握する}

土壌含水量の観測からは、はっきりした 傾向はみえにくい。土壌は、山岳の水 河や極地の水床などに比べて、地球温 暖化に対して柔軟に応答しているようで ある。土壤含水量についてすぐれた観 測データがある地域はほとんどないが、 科学者たちが 45 年にわたって土壤含 水量を測定してきたウクライナなどで も、土壌含水量の大幅な減少傾向を示 唆する証拠は見つからなかった。

米国国立大気研究所（コロラド州ボー ルダー）の気候研究者であり、「気候変 動に関する政府間パネル (IPCC)」の 筆頭著者である Jerry Meehl は、「土 猿含水量は、容易に測定できる量では ないのです」と話す。「大陸中央部で夏
季の土壌乾燥が強まることをIPCC が 最初に予測したのは、20 年近く前のこ とでした」。けれどもその後、IPCCの 予測を支持する観測も否定する観測も 行われていないため、この分野の科学 はほとんど進展していない。

どの気候モデルも、2050 年以降は 南極大陸を除くすべての大陸で夏季の 土壤乾燥が強まると予測している。しか し、どの地域で、どの程度の変化が起 こるかについては、モデルによって予 想が大きくくい違っている（下の地図を 参照)。また、Falkenmarkらの水管 理の専門家が関心をもっているのは河 川流域またはそれより小さなスケールで の土壤含水量であるが、どのモデルも、 このスケールで予測ができるだけの水 準には達していない。

あいまいさが生じる主たる理由は、 降雨モデルの構築が、気温モデルの構 築に比べてはるかにむずかしいからで ある。降雨を制御する過程（雲や水滴 の形成など）のスケールは、既存の気 候モデルが用いるスケールに比べて非 常に小さい。土壌もまた、場所による 違いが大きすぎて、現在のモデルでは 適切に再現することができない。最後 に、降雨、蒸発、二酸化炭素の濃度、 植物の成長と土袞含水量の間の複雑な 相互作用をコンピューターで処理するの は容易ではない。

土壌含水量と降雨は相互に影響を及 ぼし合うため、モデルを改良するため
にはよりよい土壌データが必要不可欠 である。しかし、世界の土袞は、気温 や降雨ほどは観測されていない。現地 での観測はほとんど行われておらず、 観測が行われている地域もまばらであ る。複雑な相互作用を解きほぐすため には、科学者は、土壤含水量を直接か つ連続的に測定する方法を考案しなけ ればならない。

そこで期待されているのが、人工衛 星を利用した観測である。欧州宇宙機関 （ESA）も米航空宇宙局（NASA）も、 ESA の ERS-1 衛星と ERS-2 衛星の任 務を拡大して、土袞含水量を観測する ミッションを計画している。計画されて いるミッションで搭載されるマイクロ波 センサーは、地球のほぼ全域をカバー し、土壤含水量をリアルタイムで測定す ることになる。植生の密度が高く、土袞 が隠れている地点では、緑の多さを土 壤含有量の代用とすることができる。

その一方で、コンピューターの処理能 力の向上は、研究者がモデルを改良す ることを可能にしている。エクセター大 学（英国）の気候モデル作成者である Peter Coxは、現在のモデルにまだ改 良の余地があることを認めている。例え ば、現在のモデルには、個々の熱帯低 気圧のモデルを構築できるほどのきめ の細かさはない。しかしCOxは、一部 の局所的モデルは、かなり細かくなって きていると指摘する。

「ポイントは、さまざまな情報源を用

\section{気候モデルが予測する土壌含水量}

3つの地図は、温室効果ガスの排出量の予測によって、1960-90年と比較した2068-98年の土 猿含水量がどのように変わってくるかを示している。それぞれの地図は異なる気候モデルに基づ いており、ポツダム気候影響研究所の科学者により、世界の植生と水のモデルに関する同一のモ デルを用いて作成された。

年間平均土壤含水量のパーセンテージ変化 (2068-98年 対 1960-90年)

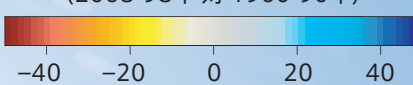

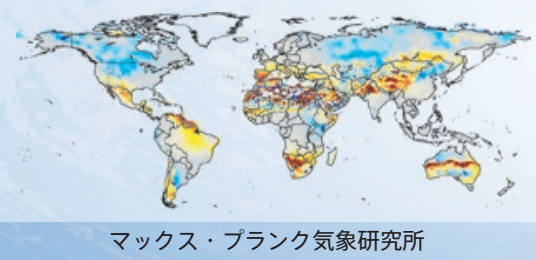

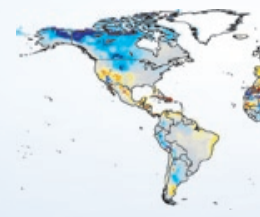

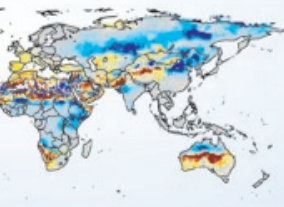

米国大気研究所

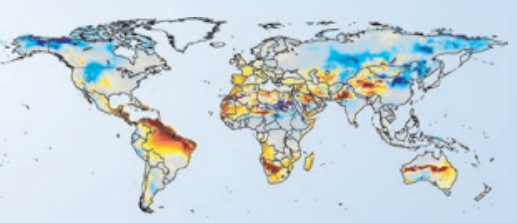

ハドリー・センター 


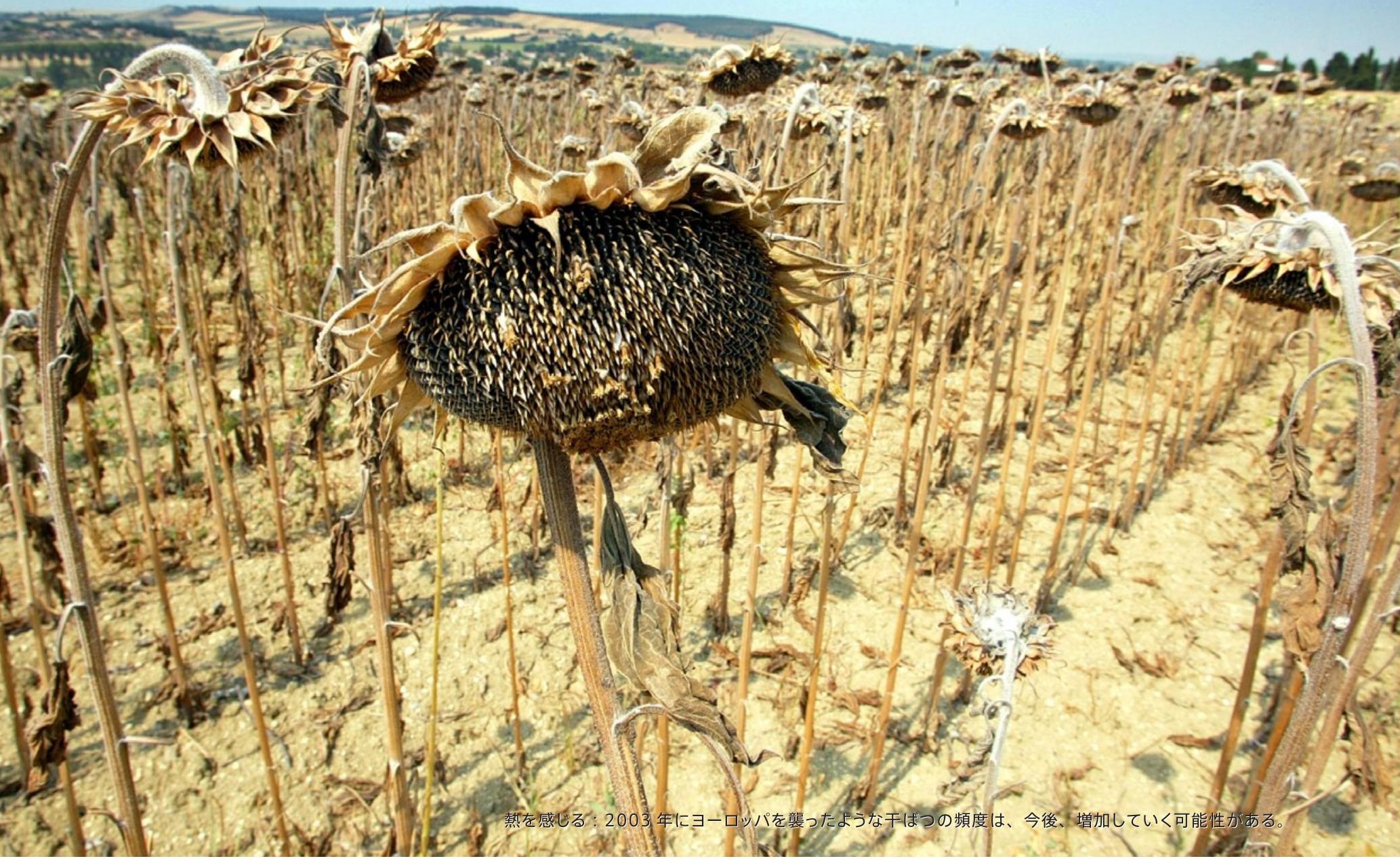

い、これらを組み合わせて、大域的な データセットを構築することにあります」 とCoxはいう。「気候モデルと人工衛 星による観測のスケールと解像度が一 致してくれば、気候モデルに衛星観測 データを取り入れて、より強力にするこ とができるのです」。

一般の人々は通常、水不足と聞けば 飲み水がなくなることを考える。けれど も、世界的な水不足がもたらす主要な 問題は、渇きではなく飢えなのである。 一般に、土㙵含水量が低下することは、 干ばつの危険が増すことを意味してい る。ゆえに、水不足の危険にさらされ ているすべての地域の作物を管理する ためには、予想される土壤含水量の変 化をモニターし、理解することが必要不 可欠なのである。

研究者は、気候変動により最も厳し い影響を受けるのは、湿潤気候から乾 燥気候への移行帯であると予想してい
る。極めて湿潤な地域では、土袞含水 量が常に多く、蒸発と降雨は土袞含水 量にほとんど影響されないし、極めて 乾燥した領域では、蒸発量が少なすぎ て、いずれにせよ、たいした降雨はな いからである。

世界気候研究計画が進めている全球 陸地 - 大気連結実験のマルチモデル研 究は、現時点で最もすぐれた見積もり の 1 つであるが、これによると、土壌 含水量と降雨を連結するホットスポット は、北アメリカ、サハラ砂漠以南のア フリカ、およびインド北部の平原にある という４。これらの地域、特にサへルか らアフリカの角にかけての「ハンガー ベルト (飢餓地帯) 」は、気候変動の 影響を最も受けやすく、干ばつや洪水 の頻度の増加や土袞浸食の加速などが 懸念されている

土壌は、植物の根の周りに雨水を蓄 える。河川や湖や地下水として蓄えら
れる水が「ブルーウォーター」とよばれ るのに対して、こうした水は「グリーン ウォーター」とよばれている。通常、乾 燥した地域では、「ブルーウォーター」 は非常に少なく、しばしば水収支の全 体の 10 パーセント未満しか占めてい ない。灌湼が普及していない熱帯およ びサバンナ地方のすべての天水農業は、 ほとんど降らない雨を蓄えるのに土壌 の能力に依存している。

1990 年代初頭に「グリーンウォー ター」という用語を作った Falkenmark は、「『グリーンウォーター』は、干ばつ が起こりやすい地域の水と食糧の安全 を守るためのかぎとなります」と指摘す る。けれども専門家たちは、世界のサ バンナ地帯（すべての大陸に存在する、 中等度に湿潤な地域から乾燥した地域) に降る雨のうち、生産的に利用されてい るのは $10 \sim 30$ パーセントにすぎない と考えている。 
食糧の供給が不安定な地域の水不 足に気候の変化が及ぼす影響は、し だいに明白になってきている。最近、 Falkenmarkをはじめとする各国の専 門家たちは、「人間が気候や水にこれだ け干渉している以上、給水管理につい ては（人間の影響を考えずに）自然の 変化のみを考えていればよいという考え 方は、もはや通用しない」と宣言した ${ }^{2}$ 。 発展途上国が現在必要としているのは、 第 2 の『緑の革命』である。その目的は、 「グリーンウォーター」の管理法を改良 し、土壌を保全し、長期にわたる乾燥 から作物を守って、作物の収穫量を増 やすことにある。

もちろん、「グリーンウォーター」と「ブ ルーウォーター」は別々の資源ではな い。灌溉は、「ブルーウォーター」を「グ リーンウォーター」に変える技術である (下の写真を参照)。しかし、乾燥した 地域では、ダムなどの技術により水の 有効利用を進めていくのは困難である。 「ですから、大部分の水技術者が、もっ ぱら『ブルーウォーター』のことばかり 考えているのは、非常に困ったことなの です」と、Falkenmark は語る。

アフリカの乾燥地域で「グリーンウォー ター」を蓄えるためには、農民は、よ り土壌にやさしい方法で畦を作るなどし て、乾燥した期間の後に降った雨が土袞 に浸透できるようにする必要がある。ラ テンアメリカでは、すでにこの方法により
収穫量を増やしている。専門家は農民に、 流去水（地中に吸収されずに流れる雨 水）を蓄えておき、作物の生育期の乾燥 した時期に使用するように勧めている。

\section{「グリーンウォーター」ヘ}

気候の変化がなくても、サバンナ地帯 の雨は不規則である。例えば、サハラ 以南のアフリカでは、「雨の多い」年に も乾燥した時期があるのが普通である。 「アフリカの『雨季』とは、雨が降るこ とが可能な季節という意味であり、雨が 降る季節という意味ではないのです」と、 Falkenmark はいう。

土壤含水量と「グリーンウォーター」 にとって、局地的な降雨の頻度と強度 は、少なくとも総雨量と同じくらい重要 である。大雨は、カラカラに乾いて硬 くなった土壌には浸透することができ ない。研究者たちは、水および土地利 用を効率よく管理することができなけれ ば、影響を受けやすい地域では降雨の 変動が大きくなり、流去水、浸食、植 物が受ける水ストレス、洪水などが増加 するおそれがあると警告している。

どの気候モデルも、地球温暖化の結 果、蒸発から降雨を経て流去に至る水 循環の全過程が増幅されると予測して いる ${ }^{5}$ 。全世界の陸地、特に、北半球 の一部や熱帯領域への降雨量はわず かに増加し、豪雨として降る雨の割合 が高くなる。
マックス・プランク生物地球化学 研究所（ドイツ、イェーナ）に所属す る炭素循環の専門家であるMarkus Reichsteinは、より極端な降雨が生 態系に及ぼす影響について検証した。 彼は、流去水から土䁃蒸発や栄養分の 利用可能性まで、生態系のすべてのレ ベルと過程が影響を受ける可能性があ ると指摘する。15名の研究者からなる 学際研究チームは、その未発表の総説 において、変化はすべての気候帯に影 響を及ぼすが、一部の生態系はほかの 生態系とはまったく異なる応答をするか もしれないと結論づけている。

温暖化する世界で植物が生き抜いて いくためには、水分と栄養分の利用可 能性の変化に適応する能力が不可欠に なるかもしれない。生態学者は、変化 がある閾値を超えると、植物がストレス を受けるようになると考えている。しか し、この閾値は生態系ごとに異なってい るため、気候の変化に対する植物の反 応にもばらつきがある可能性がある。

一般に、土袞に含まれる水分の利用 可能性は、植物の成長と光合成に制約 を課す。しかし、土䁃中の栄養分の利 用可能性は、乾燥した時期に増加する。 乾燥は、栄養分の無機化よりも、植物 による栄養分の取り込みを厳しく抑制す るからである。

それでも、すべての乾燥気味の地域 において、より極端な降雨は、作物や

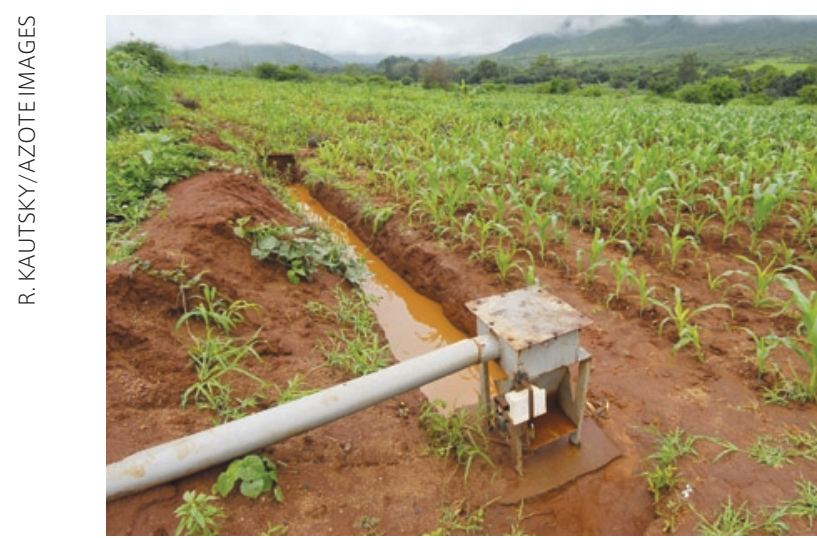

タンザニアのこの灌溉システムは、乾燥している時期の給水を補 うために雨水を蓄えるようになっている。

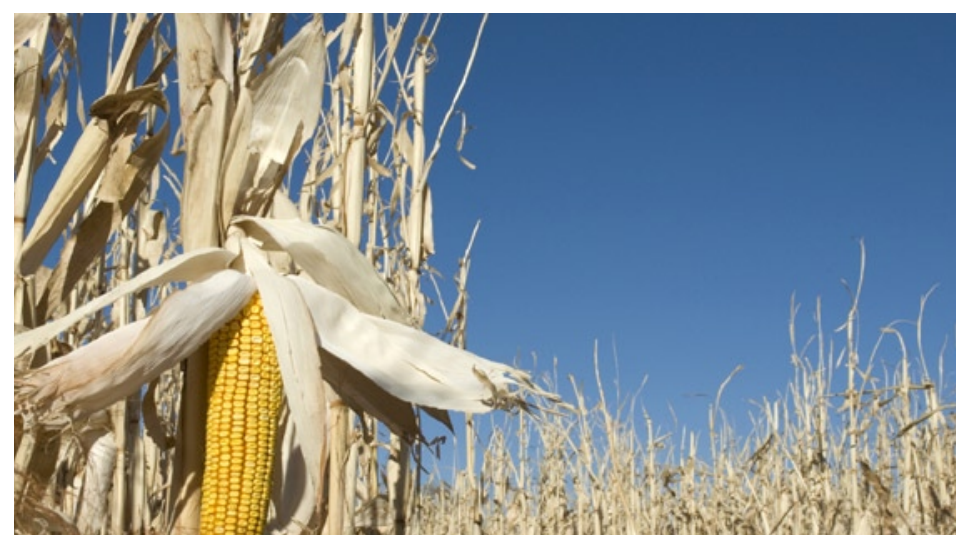

南アジアやアフリカ南部では気候変動によって、トウモロコシなどの作物が最も影響を 受けやすい。 


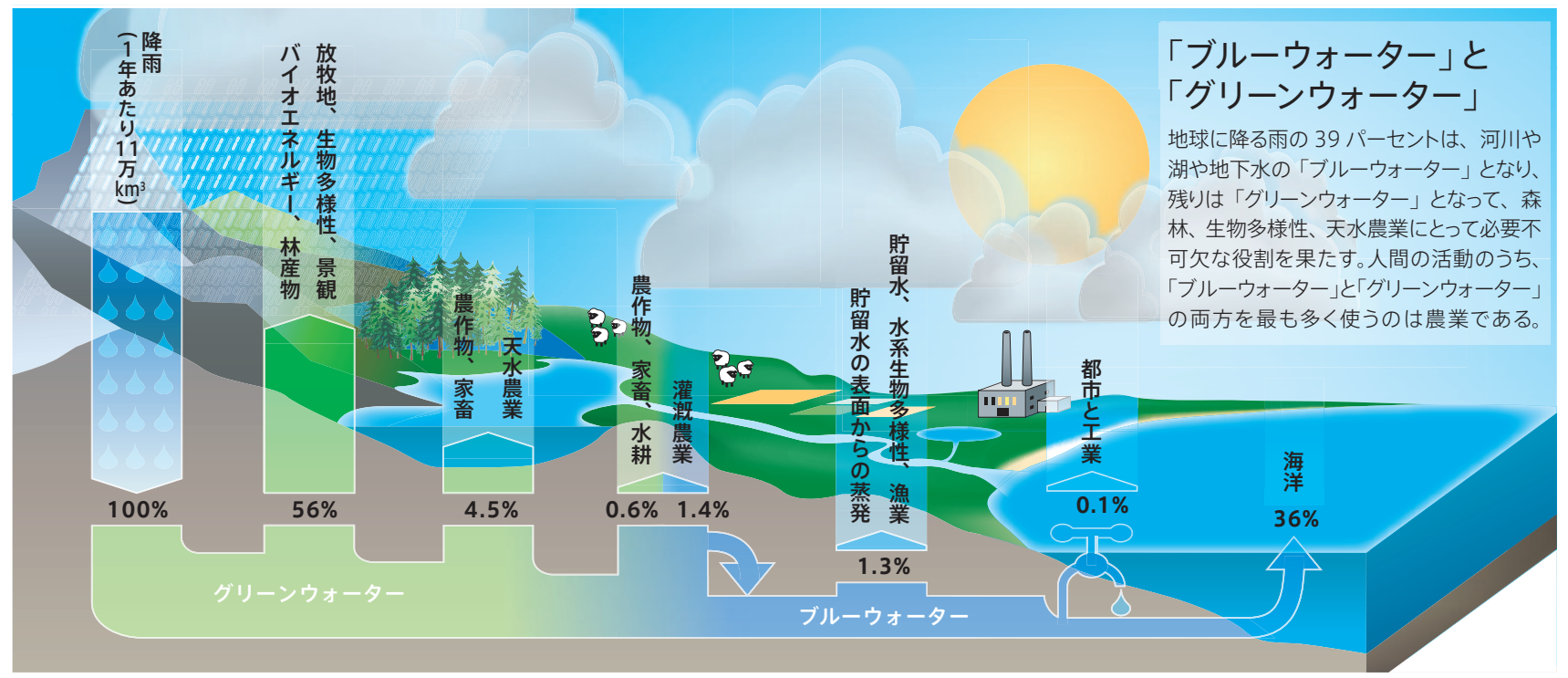

植生のストレスを増大させると科学者 は考えている ${ }^{6}$ 。残念ながら、こうした 地域は、食糧生産が不安定な人口稠密 地域でもある。サハラ砂漠以南のアフ リカでは、乾燥した時期が長くなれば 植生に悪影響が出て、灌溉により水を 補給しなければ作物の収穫量も減少す るだろう。

\section{品種改良の問題}

気候の変化に適応するにはどうすればよ いのだろうか? 2003 年にヨーロッパ を襲った熱波が一部の国々の収穫量を 50 パーセント以上も低下させたことは、 豊かな国々も地球温暖化の影響を免れ ることはできず、変化に適応していく必 要があることを示している。しかし、気 候の変化が、貧しい国々の食糧の安定 供給に対してはるかに大きな脅威となる ことは明らかである。

専門家は、発展途上国では貧困のた めに天水農業が不可能になる傾向が あると警告する。貧しい農民が作物の ために投資することができないならば、 外国からの投資援助や低利の融資が必 要である。

最近、食糧供給が不安定な12 の地 域について気候が収穫量に及ぼすリス クが分析された結果、南アジアとアフリ カ南部におけるアブラナ、トウモロコシ、
小麦などの作物が最も影響を受けやす いことが明らかになった。論文の著者ら は、農業への投資と適応のための努力 をこれらの作物と地域に集中させること を提案している ${ }^{7}$ 。

この論文の著者の 1 人であり、ス夕 ンフォード大学 (米国、カリフォルニ ア州）の農業生態学者であるDavid Lobell は、「我々は、大きな問題に直 面しています」といい、植物の品種改 良を進めるための研究資金が不十分で あると警告する。

彼は、「高温と干ばつに強い新しい品 種を緊急に開発しなければなりません。 また、トウモロコシだけでなく、ほかの 作物も必要です」と話す。「我々は、懸 命かつ迅速に取り組む必要があります。 農民たちが新しい品種を採用するまで には 15 年もの開発努力が必要になる 場合もあることを忘れてはなりません」。

しかし、国際水管理研究所（スリラン カ、コロンボ）の研究ディレクターであ り、IPCCに似た農業のための国際機 関である「開発のための農業科学技術 国際評価 (IAASTD)」の筆頭著者で あるDeborah Bossio は、まずは水 と土地の管理に対する投資がなければ、 作物を適応させる努力の一部は無駄に なってしまうと指摘する。

南アジアとサハラ砂漠以南のアフリカ
では、水への投資が特に重要であると Bossioはいう。その際には、貯水と 配水の方法について、極めて小規模の もの（土袞に蓄えられる水分やため池） から、共同体で貯水池を作る計画まで、 あらゆる可能性を考慮する必要があると 彼女はいう。

けれどもBossio は、農作物ばかり を重視していると、農作物と家畜のどち らに優先的に水をまわすべきかをめぐっ て争いになり、気候の変化の影響をさ らに受けやすくなるおそれがあると警告 する。「水不足に脅かされる地域の生 計にとって、家畜は常に非常に重要な 構成要素だったのです」と彼女はいう。 水不足への適応に関しては、人命に影 響を及ぼすすべての構成要素を考慮し ていかなければならない。

Quirin Schiermeier は、ミュンヘンに拠点を 置くNature の記者である。

1. Fischer, E. M., Seneviratne, S. I., Lüthi, D. \& Schär, C. Geophys. Res. Lett. 34, L06707 (2007).

2. Milly, P. C. D. et al. Science 319, 573-574 (2008)

3. New, M., Todd, M., Hulme, M.\&Jones, P. Int. J.Climatol. 21, 1889-1922 (2001).

4. Koster, R. D. et al. Science 305, 1138-1140 (2004).

5. Intergovernmental Panel on Climate Change in Climate Change 2007: The Physical Science Basis 760-789 (Cambridge Univ. Press, New York, 2007).

6. Porporato, A., Vico, G. \& Fay, P. A. Geophys. Res. Lett. 33, L15402 (2006)

7. Lobell, D. B. et al. Science $319,607-610$ (2008).

水特集についての詳細は、www.nature.com/news/ specials/water/index.html を参照してください。 